\title{
東京湾を例とした輻輳海域の高速航行シミュレータ実験
}

\author{
沼野 正義 * ・宮崎 恵子*・田中 邦彦*

\section{Simulator Experiment on High Speed Ship Navigation in Tokyo Bay as Example of Congested Sea Area}

\author{
Masayoshi NUMANO, Keiko MIYAZAKI and Kunihiko TANAKA
}

\begin{abstract}
High speed marine transportation has been expected as a modal shift from land transportation. A project of the Techno-Super-Liner has been carried out to realize the high speed marine transportation. The high speed marine transportation consists of not only high speed navigation in an open sea, but also those in a congested sea area, etc.. Simulator experiments in Tokyo Bay are performed to investigate effects of ship speed and other traffic conditions on the traffic safety. One of the most congested sea traffic is realized based on the field investigation of the traffic in Tokyo Bay as the scenarios of the simulator experiments. The method to apply a real time simulation of ship maneuvering motions included in a congested sea traffic to ship handling simulator experiments is proposed. Ten cases of the experiments are performed according to the proposed method. The experimental results show the possibility of high speed navigation in a congested sea area with an appropriate ship operating manual that defines standard procedures for various practical affairs involved in a real navigation. The validity of those procedures should be cleared through careful investigation in the practical operations.
\end{abstract}

\section{1.はじめに}

テクノ・スーパー・ライナー（以後TSLとよぶ）等の大型高速貨物船の開発が進められており、国内の 物流に対して、陸上輸送から海上輸送へのモーダルシフトが現実のものとなりつつある。高速海上輸送シ ステムを効率よく実現するためには、高速の巡航速度を維持するだけでなく、陸上との接点である出入港、 離着栈や港湾荷役についても迅速性が要求される。このうち、出入港等に際して通過する必要のある輻輳 海域の航行に注目し、高速航行の安全性を検討寸るため、東京湾を例として輻輳海域における高速航行の シミュレータ実験を行った。

東京湾内の船舶交通流を、実態調査 ${ }^{(1)}$ の結果を基に作成し、自船の船速を20ノット、35ノットおよび50 ットと変化させて、航行実験を行った。本論文では、操船シミュレータの航行環境としての東京湾内での 交通流の実現手法、および同シミュレータを用いた高速航行の安全性評価実験結果について述べる。

\section{2. 船舶交通流の実時間シミュレーション}

船舶技術研究所にある操船シミュレータを用いて、航行の安全性を評価する実験を行うために、実海域 の実態調查を基にした船舶交通流を実時間で表現する手法を検討し、シミュレータの交通環境として実現 した。

操船シミュレータのための船舶交通流の実時間シミュレーションは次の要件を満足しなくてはならない。 （1）対象海域、例えば東京湾全体の交通流を表現できること、すなわち、対象海域に対応した海域のひろ 巳、航行船舶数、船種等の表現。

* 正会員 船舶技術研究所（干181 三鷹市新川6-38-1） 
(2) 景観画像表示システムおよびARPA模擬装置に 被験船の周りの船舶の情報を選択的に与えられるこ r。

（3）交通流を構成する船舶についても、実時間で避 航操船等のための舵および船速制御操作が行えるこ r。

特に(1)および(3)は、実海域に近い交通流の中での シミュレータ実験を実施する上で重要である。避航 によって航行経路が大きく計画航路からそれても実 際の海域と同様の交通流が存在すること、ならびに 他船が舵操作によって変針することを模擬すること によって、シミュレータの被験者に実海域に近い他 船の動きの情報を提供できるようにする必要がある。

2.1 航行実態調查を基にした交通流の生成

実海域の航行実態調查からは、一般的に船舶交通 のOD表と発海域および着海域の組み合わせに応じて、 時間当たり、大きさによって分類された船型毎の航 行船舶数が得られる。このような場合、四 1 のよう に、各ODに対応した通航経路帯を仮定し、乱数を用 いて個々の船舶の計画航路を導き出す手法が知られ

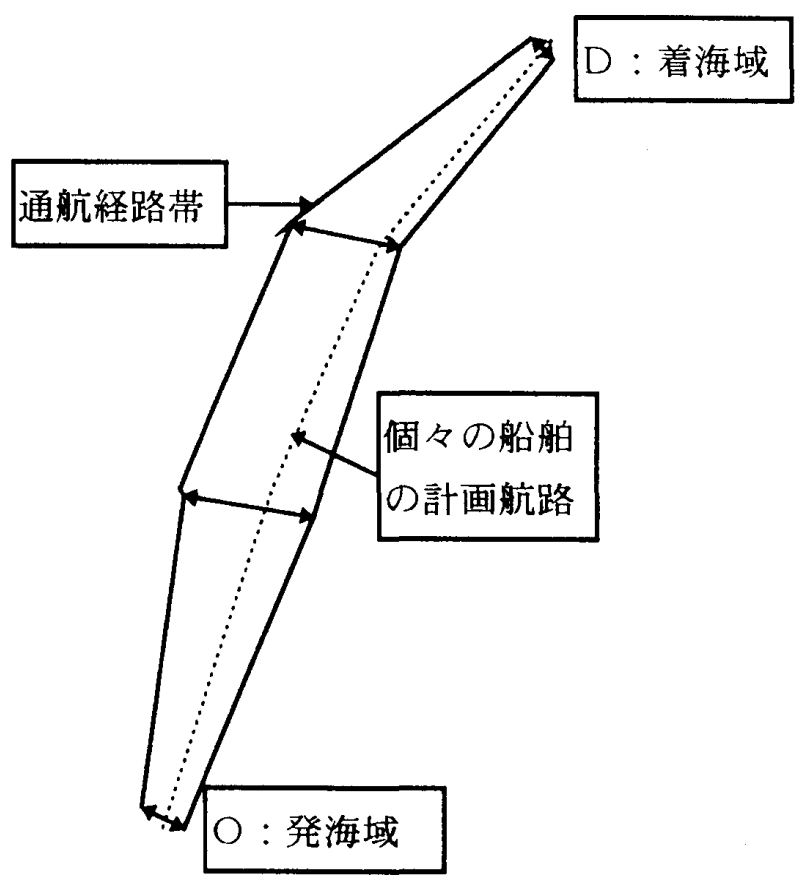

図1 交通流中の各船舶の計画航路の作成法

ている。著者らは、この手法に基づいて、シミュレータ実験の交通環境の実現に十分な助走時間を含む時 間について、あらかじめすべての船舶の発生時刻、航路点、船速等を含む計画航路を作成した。シミュレ 一タ実験に先立ち、航行船舶数が実態調查に近づくまで助走時間として、早送りシミュレーションによっ て、各船舶を計画航路に沿って航行させる。これをシミュレータ実験の交通流の初期值として用いる。

2.2 交通流の実時間シミュレーション

航行実態調查を基にした船舶交通流を適当なレベルの計算機を用いて実時間で行うためには、一般に取 り扱う船舶の総数が大きくなるためできるだけ計算機への負荷を軽く寸るようにシミュレーションのアル ゴリズムを設定する必要がある。この観点から、シミュレーションのアルゴリズムは、次の項目のように 整理できる。

（1）船舶の発生：あらかじめ、交通流中で発生する船舶を、発生時刻順に並べ替えて、シミュレーション 時刻と比較するためのポインタを最も発生時刻の早い先頭の位㯰に設定する。また、各船舶毎に交通流中 に存在するかどうかを示すフラグを定義し、初期値としてOFFを設定する。シミュレーション実行中は、 シミュレーション管理時間刻み每に時刻と次に発生が予定されている船舶の発生時刻だけを比較し、発生 時刻になったらその船舶の存在フラグをONにするとともに、比較のポインタを一つ進める。この手法によ り、船舶発生にかかる負荷を軽減することができる。

(2) 船舶の操糈運動の計算：シミュレーションの時間刻み每に、存在フラグがONの船舶について、次式の ような操縦運動モデルを仮定して、船舶の運動を計算する。

$$
\begin{aligned}
& d R d / d t=(R o-R d) / \tau_{r} \\
& d \omega / d t=\left(\omega_{\max } * R d / R d_{\max } * v / v_{\max }-\omega\right) / \tau_{\omega} \\
& d h / d t=\omega \\
& d P s i / d t=(h-P s i) / \tau_{p} \\
& d v / d t=\left(v_{o}-v\right) / \tau_{v}
\end{aligned}
$$

ただし、Ro：指令舵角、 $R d$ : 実舵角、 $\tau_{r}$ : 舵遅れ時間、 $\omega$ : 旋回速度、 $\omega_{\max }$ : 最大旋回速度、 $R d_{\text {max }}$ : 最 大舵角度、 $v$ : 船速、 $v_{\max }$ : 最大船速、 $\tau_{\omega}$ : 旋回遅れ時間、 $h$ : 針路、Psi: 船速方位、 $\tau_{p}$ : 船速方位遅れ時 間、 $v_{0}$ : 指令船速、 $\tau_{v}$ : 船速遅れ時間とする。操縦運動計算の時間刻みは、それぞれの遅れ時間に比べて十 分小さいものとする。このモデルを用いると、交通流中で大きさ別に分類されている船舶に適当な操縦性 能を与えることが容易である。 
（3）計画航路上のトラッキング：シミュレーションの管理時間刻み毎に存在フラグがONの船舶に対して計 画航路に沿ったトラッキングを行う。トラッキングは、各船舶の計画航路からの変位を基に、指令針路を 決定し、オートパイロットアルゴリズムにより指令舵角を決定する。また、必要に応じて、指令船速を変 更する。船舶がそれぞれの着海域に到達したら存在フラグをOFFにして、シミュレーションから消去する。 (4) 海域の管理：対象海域を一定距離間隔のメッシュに分割し、シミュレーション管理時間刻み毎に、各 海域毎のその中に存在する船船のリス卜を作成する。被験船の周りにその航行に影響を与えるであろう適 当な広さを設定し、この中にある海域メッシュに含まれる船舶のリストを作成する。このリストに従つて、 景観画像表示システムおよびARPA模擬装置に、船位等の必要な船舶のデータを送信する。一度全船舶を リスト化すれば、個々の船舶に対するシミュレーション実行上の様々な処理は現在存在する船船だけを対 象とすることとなり、長時間のシミュレーションにおいても計算機への負荷を軽減することができる。

現時点では、交通流内の船舶同士の避航は模擬していないが、この海域メッシュ毎の船舶りストを利用 して避航対象船舶を絞ることにより、交通流内の船舶同士の避航の実現が可能であると考える。また、海

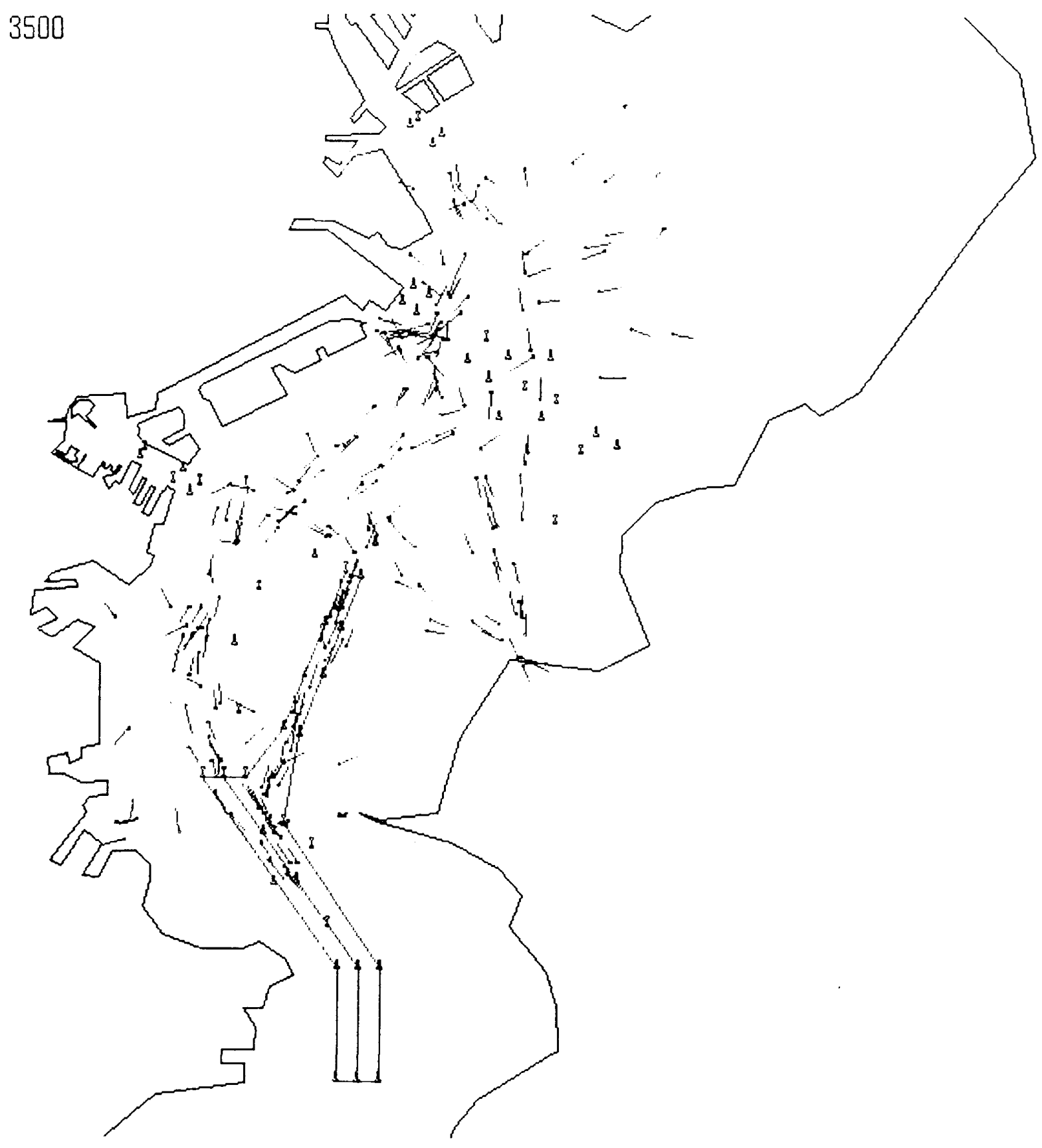

困 2 シミュレータ実験に用いた東京湾の船舶交通流 
域每にネットワーク上の別々の計算機で、自動航行 アルゴリズムを動作させて、それぞれの船舶の操船 指令を決定することにより、さらに広範囲の海域で の船舶交通流の実時間のシミュレーションが可能で あり、実航路を想定した長時間のシミュレータ実験 が可能となる。

\section{3 . 東京湾を例とした高速航行シミュレータ実験}

上記の手法を用いて、東京湾の交通流実態調査 ${ }^{(1)}$ に 基づいて船舶交通流を作成し、輻輳海域における高 速航行のシミュレータ実験を行った。いくつかの時 間帯を比較検討し、最も船舶の航行数が多かった、 朝 7 時からの 1 時間のデータを用いて、各OD和よび 各船型に応じた発生頻度に従って 2 時間分の計画航路を作成した。交通流を構成する船舶の操縦性能抢よ び景観画像で用いる外観は、船舶の大きさによる船型の各分類に応じて決定した。助走時間として約 1 時 間早送りシミュレーションの後、被験船を所定の海域に発生させてシミュレータ実験を行った。被験船は、 TSLのAタイプを想定し、その操縦性能は、舵角指令から旋回までの応答遅れ時間がトータルで 5 秒程度、

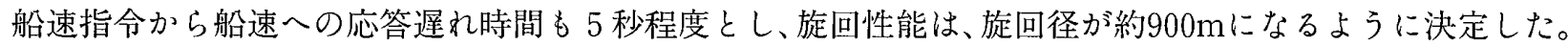
2 時間の総発生船舶数は、約 600 隻である。図 2 に、約 1 時間助走後の「整流」時の東京湾全体の船舶交通 流を示す。四中では、海岸線と浦賀、中ノ瀬航路と主要灯浮標の位置を示すとともに、小さい○が航行船 舶の船位を示し、船位からのびた線分が 3 分間の速度ベクトルを示している。

\section{1 実験条件}

輻輳海域における高速航行の安全性を評洒するために、被駼船の船速を20、35、50ノットの 3 段階、航 路の屈曲や他の航路との交差の影響を評価するために、中ノ瀬航路出口付近から東京灯標付近までの北航 と東京灯標付近から浦賀水道航路入口までの南航について実験を行った。また、船舶交通流の整流度の影 響を評価するために、実態調査通りの「整流」状態と実態調査のOD表には従うが、計画航路へのトラッキ ングアルゴリズムを変更した「非整流」状態の交通流について実験を実施した。「整流」状態では、同航、 反航まよび横切り等、他の船船の動向が東京湾の実態と合致していることからその予測が比較的容易であ ると考えられる。これに反して、「非整流」状態においては、他船の航行状況が害態と異なるため、その動 向の推定が困難であり操船負担が増大することが考えられる。被験者は、TSLAタイプ実海域実験船「飛翔」 の船長および一等航海士の 2 人にお願いし、船長が航行の意思決定およびへルムを、一等航海士が目視お よびARPA等の情報支援を担当する 2 人当直体制で操船していただいた。

船速 20 ノット、35 ノット、 50 ノットの 3 つの条件、北航および南航の 2 つの条件、「整流」状態と「非整

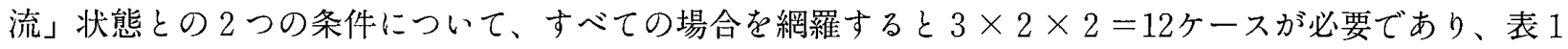
の順番で条件を設定して実施した。実験番号95121301はシリーズの第 1 番目であり予備実験 と位置づけて いる。また、実験番号95121402（北航、35ノット、非整流）およ゙95121403（南航、50ノット、非整流） は、航跡データの記録が取れなかったので表から削除している。実験日程の制限から、「北航、35ノット、 非整流」、北航、50ノット、非整流」および「南航、20ノット、整流」の各ケースは実施できなかった。

被験者には、各実験ケース毎に指定された船速で航行寸るとともに、「飛翔」の運航経験に基づき、安全 を担保するとともに、一般船に衝突の脅威を感じさせないような航行方法をとることと、安全を担保する 上で必要と判断した場合は減速しても良いとの条件を与えて実験を行った。

\section{2 実験結果および考察}

3.2 .1 危険な見合い関係の抽出

各実験ケース毎に、アンケートおよびインタビューにより被験者の主観的評洒と操縦結果としての航跡 記録を採取した。この航跡記録を基に、被験船から 3 分以内に 0.2 海里より近づく危険性のある船舶を抽出 したリストの例が表 2 である。表 2 (1)は船速20ノットの南航、「非整流」であり、表 2 (2)は船速50ノットの 南航、「整流」である。表 2 (1)は船速が小さいため 3 分間ベクトルの長さが 1 海里となり、上記の分類によ 
表 2 (1) 衝突危険のある見合い関係の抽出例(1)

\begin{tabular}{|c|c|c|c|c|c|c|c|}
\hline \multicolumn{2}{|c|}{95121302} & $20 ノ ッ ト$ & \multirow{2}{*}{ 南航 } & \multicolumn{4}{|l|}{ 非整流 } \\
\hline 時刻 & 船舶番号 & $\begin{array}{l}\text { 航過距離 } \\
\text { (m) }\end{array}$ & & $\begin{array}{l}\text { 一般船からみた } \\
\text { C PA (度) }\end{array}$ & $\begin{array}{l}\text { 高速船からみた } \\
\text { C PA (度) }\end{array}$ & $\begin{array}{l}\text { 避航開始距離 } \\
(\mathrm{m})\end{array}$ & $\begin{array}{c}\text { 時間余裕 } \\
\text { (秒) }\end{array}$ \\
\hline 294 & 133 & 766 & & 234 & 358 & & \\
\hline 330 & 194 & 458 & & 298 & 197 & 1200 & 120 \\
\hline 414 & 119 & 388 & & 67 & 147 & & \\
\hline 468 & 21 & 721 & & 85 & 98 & & \\
\hline 561 & 238 & 423 & & 306 & 198 & & \\
\hline 645 & 30 & 295 & & 94 & 81 & & \\
\hline 702 & 121 & 408 & & 244 & 345 & 1450 & 140 \\
\hline 981 & 23 & 335 & & 73 & 132 & & \\
\hline 1044 & 17 & 235 & & 250 & 304 & & \\
\hline 1431 & 148 & 311 & & 118 & 352 & & \\
\hline 1671 & 115 & 629 & & 289 & 229 & & \\
\hline 1890 & 469 & 239 & & 260 & 291 & 1100 & 110 \\
\hline 1947 & 495 & 569 & & 261 & 285 & & \\
\hline
\end{tabular}

る危険な船舶との遭遇の総数は少ない。表 $2(2)$ は船速が大きいため 3 分閒ベクトルの長さは 2.5 マイル となり、航路が屈曲が大きいこととあいまって、危険な船舶との遭遇の総数は多くなっている。遭遇時刻 順に時刻、船舶番号、航過距離、航過時の一般船および被験船の双方からみた最接近点の方位等を示す。 これらの遭遇船舶のうち、避航の対象となったと判断されたものについては、避航開始距離と避航開始時 の最接近時間を求めている。

\section{2 .2 避航操船の評価}

各実験の終了直後に被験者にインタビュ一を実施した。インタビューでは、(1) 陸岸等により航行の制限 を受けたかどうか、(2) 相手船に脅威を与えたかどうか、(3) 情報処理や判断のための余裕があったか、に ついて回答を求め、さらにその他の意見を述べてもらった。回答の主なものを、抜粋する。

実験番号121302（南航、20ノット、非整流）

・陸岸により操船が制限されることはなかったが、270度で右に舵をとって相手船の前を通ったところがあ ったが、左の方が良かったかもしれない。右にとったのは他の船に挟まれることのないように安全なコー スをとるためであった。この実験の中では情報処理の最も難しいぎりぎりのところであった。

・それ以外は不安を与えていない。

・情報処理の時間はあった。

・20ノットは10ノットよりしんぞい。判断時間が短くなることが一つの理由である。この実験のシナリオ は（実験番号 $121301 に$ 比べて）遭遇数が増え、難しい遭遇も多かった。

・この実験のシナリオは、整流されているべきところに横切り船や逆行船がある。航路網が違う。常識的 な走り方でないので判断に時間がかかる。

・視界は 2 マイルの感じで、航行が難しい。

実験番号121404（南航、50ノット、整流）

・陸岸による操船の制限はなかった。

・情報処理をする時間は十分にあった。

・周りに脅威を与兄なかった。

・船の流れが常識的に理解できるから、判断、操船がやりやすかった。

・南航では、ブイから1000m離すように行政指導されているが、交通流によって、北航の船がなければブイ 
表 2 (2) 衝突危険のある見合い関係の抽出例(2)

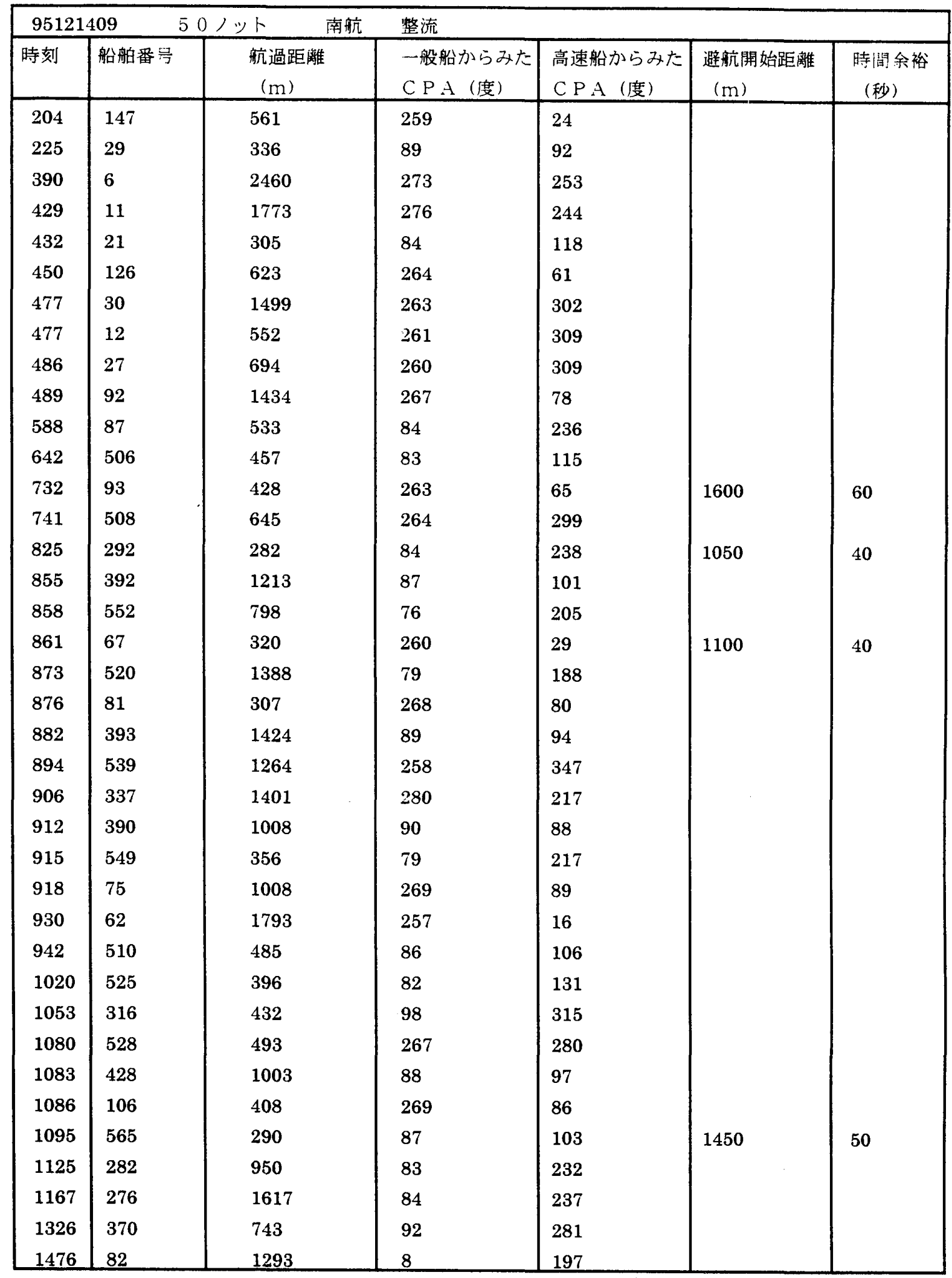

の近くをを航行する方が安全ではないか。

実験番号 121405 (北航、20ノット、整流)

・工事ブイによる操船の制限があった。

・相手船の意思がわからず、 3 番ブイの近くまでいった。 
・情報処理をする時間は十分あった。

・周りに脅威を与えなかった。

・20ノットではリズムに乗れない。次にぼうするかを考えている時間が長いので、緊張が持続できない。 ・50ノットでは少数の船、20ノットでは多くの船を対象とする。よって、処理にかかる時間の割合は同に゙ ではないか。20ノットでは時間的な余裕はあるが対象船が多いし、時間のある分だけ多くを考えてしまう。 これらを総合して、被験者の自己評価はつぎようにまとめることができる。

(1) すべての実験において、一般船に衝突の努威は与えなかった。

(2) 今回の実験海域程度の輻輳度においては、避航操船のための余裕は十分であった。

(3) 10 ノットよりも20ノットの方が判断時間が短くなるため操船負担が大きかった。

(4) 20 ノットでの航行と50ノットでの航行とを比較すると、20ノットの方が危険な見合い関係が長時間持 続するため、かえって操船負担が増大した。

（5）「非整流」の場合は、相手船の動向が予測しにくいので、判断に時間がかかった。

高速船側からみた安全性については、避航操船後の見合い関係をあらかじめ予測して安全を確認しなが ら、避航操船を実行していることが実験中の観察およびインタビュ一等を通してわかり、参考文献(2)にお いて著者らが提案している作業レベルによる安全余裕の評価における最も余裕のある場合である「大局的 判断が可能」というレベルであったことがわかった。

次に、参考文献(3)の実船およびシミュレータ実験による一般船に妿威を与兄ない見合い関係に関する知

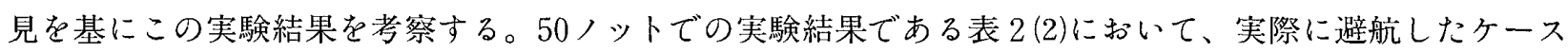
について、避航方法は一般船の船尾航過が多く、避航開始距離は $1000 \mathrm{~m}$ 以上であった。避航開始距離がささ いケースを個別に分析すると、他の船舶を避航している途中で一時的に対象となった船舶と衝突の危険の ある見合い関係になったものであり、一般船からは被験船の避航の意志が理解できると考兄ることができ る。今回の実験ではケース数が少ないためこのデータから絶対的な数值を論じることはできないが、これ らの避航操船のうちで最も小さかった避航開始距離の $1050 \mathrm{~m}$ は実験から得られた知見として、参考文献(4)に おいて、輻輳海域における一般船に衝突の危険感を与えない航行方法のモデル化の資料として用いられて いる。

\section{2 .3 総合評価}

今回の、束京湾を例とした輻輳海域の高速航行シミュレータ実験の結果から、船舶の輻輳度の観点から は、適切な運航体制が整えば50ノットの船速においても高速船側の余裕および操船結果として一般船側に 脅威を与えないで航行することが可能であることがわかった。船舶交通流の「整流」「非整流」の影響に ついては、「非整流」の場合には、一般船が不意に変針を始めるなぼ航行の意志の推定が困難であったこと がインタビュー結果として得られており、安全性の向上に交通流の整流が有効であることがわかった。

実船への適用については、今回のシミュレータ実験に含まれなかった操業中の漁船や、その他の考慮し ておくべき不測の事態への対応策等を十分に考慮しつつ、段階的に進める必要があると考える。被験者へ のインタビューから、「大局的な判断が可能」な安全余裕を担保できる範囲では船速が大きいほうが操船し やすいという主観的評価が得られており、高速船の船速は輻湿度と、船舶の操縦性能、当直体制等の安全 对策等を総合的に判断して適当な船速を決定できると考えられる。

しかし、今回は実験ケースが限られていたため、実船への適用に先立って、さらにシナリオ等を吟味し た実験を行うことが必要である。

\section{4. おわりに}

輻輳海域における高速航行の安全性評洒のためのシミュレータ実験を可能とするために、船舶交通の実 態調査を基にした交通流シミュレーションを実時間で実施し、航行シミュレータ実験の交通環境として用 いる手法を開発し、これを用いて東京湾を例とした輻輳海域の高速航行シミュレータ実験を実施した。

輻輳海域での高速航行における、船速、および整流の影響を明らかにするために、これらをパラメータ としたシミュレータ実験を行い、東京湾の最も船舶数の多い時間帯においても、50ノット程度の船速での 航行が、高速船側の余裕および一般船側からみた妿威の観点から可能であることがわかった。実船への適 用については、対象船船および対象海域に即したシミュレータ実験を行って安全性の確認を行う必要があ 
る。さらに、当直体制や操業漁船群との遭遇等の高速航行に大きく影響を与える事象への対応策を事前に 検討し、これらを規定した運航マニュアルを整備することが必要である。これらを実施した上で、実船で の検証を経ることにより段階的に安全な航行が実現できると考える。

今回開発された手法は、実海域を模擬した交通流中の航行シミュレータ実駼を可能をするものであり、 今後、実海域における一般船同士の避航操船等をシミュレータ上で実現できるよう機能を拡張していきた い。

謝 辞

今回、東京湾の交通流をシミュレータ実験海域内に実現寸るに当たり、参考文献(1)の調查結果を利用さ せていただいた。

シミュレータ実験の被験者として協力いただいた、TSL「飛翔」の船長岡村米作氏および一等航海士伊 予谷一成氏に感謝いたします。また、当シミュレータ穾験に先立つて実施された実船実験およびシミュレ 一夕実験による高速船と一般船の見合い実験に協力いただいた方々に涾く感謝いたします。

\section{参 考 文 献}

（1）「東京湾口航路航行船舶実態調查報告書」，運輸省第二港湾建設局京浜事務所， 1990 .

（2）沼野他；船舶航行における潜在的危険の評価，日本航海学会論文集85号，pp.25-31，1991.

(3) 宮崎他; 高速船と一般船の見合い実験一実船実験とシミュレー夕実験一, 日本航海学会論文集 95 号 (予 定), 1996.

（4）村山 他；輻輳海域における高速船の安全な航行方法（高・低速 2 船間の見合い関係における衝突の 危険回避モデル化)，日本航海学会論文集95号（予定），1996.

\section{質 疑 応 答}

鈴木三郎 (神戸商船大学)：「段階的な高速航行が実現できる」と結論付けられているが、このシミュレー 夕実験では、「段階的な」という結論はでないと思う。シミュレータのシナリオ条件で安全航行ができた か否かという答えのみであると思う。漁船の存在の有無のシナリオ条件は、「段階的な」という条件では ないと判断するが、いかがか。

沼野正義：シミュレータ実験の結果から、シナリオとして用いた東京湾の輻輳度の程度の海域においては、 50 ノットでの高速航行に対して、通常時は安全余裕の観点からみて十分安全な航行が可能であると考え らる。しかし、実際の海域での航行は、操業中の漁船との遭遇等、シミュレータ実験シナリオに含まれ ない事象が多く存在するが、これらについてはシミュレータ実験とは別に事前に対処方針を検討して、 運航マニュアルの中に規定するべき事項と考える。よって、この運航マニュアルを遵守しつつその内容 が妥当であることを、はじめは安全担保のための制限を加えたうえで、実海域での航行を通じて検証す ることにより、検証された部分から段階的に制限を緩めることができるなら、高速航行の実現が可能で あり、この意味での段階的な実現が可能であると考える。

長澤 明 (海上保安大学校)：(1) 背景としての交通流の設定に「非整流」のケースもあるとのことだが、 「非整流」とはどのような設定か。

（2）速力、交通流等のパラメータに加え、被験者も含めた実験数（データ数）を示してほしい。

沼野正義：(1) まず、「整流」とあるのは、交通流の実態調查に基づいて、各船舶の計画航路を作成し、こ れに沿ったトラッキングを行った場合をいっている。これに対して、「非整流」は各船舶の計画航路は、 「整流」の場合と同じであるが、計画航路から左に大きく膨らんで航行するようにトラッキングのアル ゴリズムを変更した場合をいう。結果として、東京湾内の通常の航行方法と異なり外部からは予測の難 しい行動をとることになる。

（2）今回の実験は、予備実験を含めて 2 日間にわたったが、実施時間が限られていたため、10ケースし か実施できなかった。実験番号および各実験条件は本文表 1 の通りである。議論を進める上で必要であ ればシミュレータ実験を追加実施することも考えている。 